Article

\title{
Temperature-responsive self-separation ionic liquid system of zwitterionic-type quaternary ammonium-KI for $\mathrm{CO}_{2}$ fixation
}

\author{
Xiying Fu a,t, Pengtao Xie b,t, Yiwei Lian a, Leqin He a, Wei Zhao c, Tao Chang a,*, Shenjun Qin a,\# \\ a College of Material Science and Engineering, Hebei University of Engineering, Handan 056038, Hebei, China \\ b College of Chemical Engineering and Materials, Handan College, Handan 056005, Hebei, China \\ c College of Chemistry and Pharmaceutical Engineering, Nanyang Normal University, Nanyang 473061, Henan, China
}

\section{A R T I C L E I N F O}

\section{Article history:}

Received 31 March 2018

Accepted 14 May 2018

Published 5 November 2018

\section{Keywords:}

Carbon dioxide

Self-separation

Cyclic carbonate

Zwitterionic-type quaternary

ammonium

$\mathrm{KI}$

\begin{abstract}
A B S T R A C T
A series of zwitterionic-type quaternary ammoniums (ZTQAs) with varying lengths of alkyl chains combined with $\mathrm{KI}$ were synthesized and considered as catalysts for the coupling reaction of $\mathrm{CO}_{2}$ and various terminal epoxides. The prolonged alkyl chain of ZTQAs exhibited temperature-responsive self-separation in propylene carbonate (PC). The interaction between ZTQAs and KI was confirmed by X-ray photoelectron spectroscopy and quantum chemical calculations. This interaction strengthened the nucleophilicity of the $\mathrm{I}^{-}$ion, favoring the catalytic reaction. The 3-(dimethyltetradecylammonium) propane sulfonate (DTPS)/KI showed an excellent yield of PC $(95.1 \%)$ at $125^{\circ} \mathrm{C}, 1.5 \mathrm{MPa}$, and $1 \mathrm{~mol} \%$ loading of catalyst. The precipitate formed spontaneously from the catalytic system, providing high catalytic activity of the homogeneous catalyst, as well as easy recovery of the heterogeneous catalyst.
\end{abstract}

(C) 2018, Dalian Institute of Chemical Physics, Chinese Academy of Sciences. Published by Elsevier B.V. All rights reserved.

\section{Introduction}

The demand for energy has significantly increased due to the global economic development. In the atmosphere, the amount of $\mathrm{CO}_{2}$ generated has surpassed the consumption capacity of plants and microorganisms by photosynthesis, resulting in a rapid increase in the $\mathrm{CO}_{2}$ concentration. In 2015, the concentration of $\mathrm{CO}_{2}$ crossed $400 \mathrm{ppm}$, leading to global warming [1]. Therefore, it is important for governments to adopt new policies to decrease $\mathrm{CO}_{2}$ emissions. However, $\mathrm{CO}_{2}$ could also be regarded as the most abundant carbon feedstock in the C1 family, with several advantages, such as low cost, nontoxicity, as well as non-flammability [2-7]. Thus, the conversion of $\mathrm{CO}_{2}$ into high-value products has several economic advantages [8]. Among these products, five-membered cyclic carbonates, which can be synthesized via the coupling reaction of $\mathrm{CO}_{2}$ and epoxides, have gained significant attention [9-13]. These cyclic carbonates are extensively used not only as favorable polar aprotic solvents, but also as electrolytes in batteries and as important precursors in the synthesis of chemicals, drugs, and polymers [14-16].

In recent decades, especially, the cycloaddition of $\mathrm{CO}_{2}$ with

\footnotetext{
* Corresponding author. Tel/Fax: +86-310-8578760; E-mail: changtao@hebeu.edu.cn

\# Corresponding author. Tel/Fax: +86-310-8577902; E-mail: qinsj528@ hebeu.edu.cn

${ }^{\dagger}$ Contributed to this work equally.

This work was supported by the National Natural Science Foundation of China $(41330317,21403051)$, the Natural Science Foundation of Hebei province (B2016402030, B2017402079), the Science and Technology Foundation of Universities of Hebei Province (ZD2015113), the Science and Technology Research Development Program of Handan (1621211041-3, 1622201049-2), and the Program for One Hundred Innovative Talents in Universities of Hebei Province (BR2-204).
}

DOI: 10.1016/S1872-2067(18)63101-8 | http://www.sciencedirect.com/science/journal/18722067 | Chin. J. Catal., Vol. 39, No. 11, November 2018 
epoxides has attracted an unprecedented research interest. Various catalytic systems have been developed for this reaction, including homogeneous [17-38] and heterogeneous catalysts [39-57]. In particular, in the category of inexpensive green catalysts, alkali metal salts have played an important role in developing a new catalyst system for coupling reactions [58-67]. Generally, homogeneous catalytic systems exhibit high catalytic activities in coupling reactions. However, it is challenging to separate the products and recover catalysts from these systems. To avoid the problems caused by homogeneous catalysts, several heterogeneous systems, which can be separated easily, are used as catalysts for these reactions. Nevertheless, harsh reaction conditions, such as high temperature, high pressure, and long reaction times, are required, which hinder the application. Therefore, there is an urgent need to discover a system that offers high catalytic activity, as well as easy recovery of catalysts.

To overcome the aforementioned disadvantages, ionic liquids can be used. They provide a powerful approach to resolving mass transfer limitations with catalytic reactions [68,69]. They are in a homogeneous phase with the reactants, while the products are formed during the catalytic reaction at the reaction temperature. Moreover, the temperature-responsive ionic liquids, which precipitate spontaneously at lower temperatures, can be easily separated from the reaction systems [70]. Some temperature-responsive ionic liquids composed of polyether tags, polyoxometalate, and carboxylic acid were used in catalytic reactions, such as hydroformylation [71], coupling reactions [72], oxidation reactions [73], biomass conversion [74], condensation [75], esterification [76], and cycloaddition of $\mathrm{CO}_{2}$ with epoxides [77]. All of the aforementioned catalytic systems exhibited excellent catalytic activities and easy recovery of catalysts. In the light of these advantages, a series of sulfonate functional zwitterionic-type quaternary ammoniums (ZTQAs) (Scheme 1) combined with KI were explored for the coupling reaction of $\mathrm{CO}_{2}$ and epoxides.

\section{Experimental}

\subsection{Materials}

All tertiary amines were purchased from Energy Chemicals, including $\mathrm{N}, \mathrm{N}$-dimethyl butylamine, $\mathrm{N}, \mathrm{N}$-dimethyl octylamine, $\mathrm{N}, \mathrm{N}$-dimethyl dodecylamine, $\mathrm{N}, \mathrm{N}$-dimethyl tetradecylamine, $\mathrm{N}, \mathrm{N}$-dimethyl hexadecylamine, and $\mathrm{N}, \mathrm{N}$-dimethyl stearylamine.

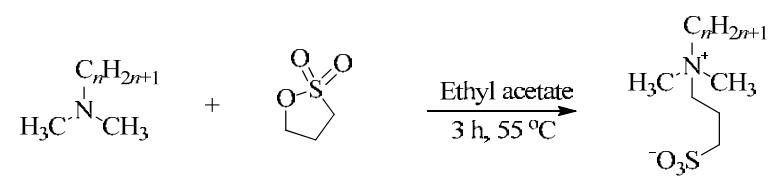

$n=4,3$-(dimethylbutylammonium) propane sulfonate, DBPS

$n=8,3$-(dimethyloctylammonium) propane sulfonate, DOPS

$n=12,3$-(dimethyldodecylammonium) propane sulfonate, DDPS

$n=14,3$-(dimethyltetradecylammonium) propane sulfonate, DTPS

$n=16$, 3-(dimethylhexadecylammonium) propane sulfonate, DHPS

$n=18$, 3-(dimethylstearylammonium) propane sulfonate, DSPS

Scheme 1. Route for synthesis of sulfonate functional ZTQAs.
$\mathrm{CO}_{2}$ was supplied by Handan Anke Factory with a purity of 99.99\%, while 1,3-Propane sultone (99\%) was purchased from Aladdin Reagent Co., Shanghai, China. Propylene oxide, butylene oxide, epichlorohydrin, and cyclohexane oxide were obtained from Energy Chemicals. Styrene oxide and phenyl glycidyl ether were supplied by J\&K Chemicals. All reagents purchased were of analytical grade. They were purchased from commercial sources and used without any further purification. DBPS, DOPS, DDPS, DTPS, DHPS, and DSPS were synthesized according to the previously described protocol $[78,79]$.

\subsection{General procedure for the coupling reaction of propylene oxide and carbon dioxide}

An amount of propylene oxide (PO; $50 \mathrm{mmol}$ ) was placed into a $100-\mathrm{mL}$ stainless steel autoclave equipped with a magnetic stirrer and an automatic temperature control system. The desired amounts of ZTQAs and KI were introduced into the autoclave. The sealed container was charged with carbon dioxide at an appropriate pressure. The reaction was started at the predetermined temperature. After the reaction was complete, the container was cooled to room temperature and the unreacted $\mathrm{CO}_{2}$ was vented. The crude product was separated from the system by centrifugation. The catalyst was washed by $\mathrm{Et}_{2} \mathrm{O}$ and dried under vacuum for future use.

\section{Results and discussion}

\subsection{ZTQA screening for the coupling reaction of $\mathrm{PO}$ and $\mathrm{CO}_{2}$}

Generally, the polarity of molecules can be modified by changing the length of the alkyl chain, which has a profound impact on catalysis. Therefore, a series of ZTQAs with varying alkyl chain lengths was synthesized (Scheme 1). The effect of various ZTQAs with $\mathrm{KI}$ on the coupling reaction of $\mathrm{CO}_{2}$ was investigated. The results are illustrated in Table 1, with the model reaction of $\mathrm{PO}$ and $\mathrm{CO}_{2}$. Nearly no reaction was observed with ZTQAs as the only catalyst, whereas KI could catalyze the coupling reaction alone, although the yield was relatively low (entry 1). Notably, when both ZTQAs and KI were in the reaction, an increase in the yield of propylene carbonate (PC) was

\section{Table 1}

Effect of the structure of ZTQAs.

\begin{tabular}{|c|c|c|}
\hline Entry & Catalyst system & Yield (\%) \\
\hline 1 & $\mathrm{KI}$ & 23.7 \\
\hline 2 & DBPS/KI & 74.1 \\
\hline 3 & DOPS/KI & 75.4 \\
\hline 4 & DDPS/KI & 74.5 \\
\hline 5 & DTPS/KI & 75.5 \\
\hline 6 & DHPS/KI & 64.7 \\
\hline 7 & DSPS/KI & 41.2 \\
\hline 8 & ZTQAs & $\mathrm{NR}^{\mathrm{a}}$ \\
\hline
\end{tabular}


detected (entries 2-7). Thus, it is clear that ZTQAs play an important role in realizing the coupling reaction. In addition, ZTQAs with varying alkyl chain lengths exhibited different catalytic performances, even though similar catalytic activity was observed for the alkyl chain group ranging from butyl to tetradecyl, as demonstrated (entries 2-5). Unfortunately, by prolonging the length of the alkyl chain further, an opposite tendency was observed (entries 6, 7). When the catalyst was DTPS with tetradecyl, the best yield obtained was $75.5 \%$. To investigate this, the solubility of various ZTQAs in PC was analyzed and listed in Fig. S1 and S2. At the initial stage of heating, all the catalytic systems, except for those of DHPS/KI and DSPS/KI, dissolved completely in PC, resulting in lower activities for these two systems. After cooling, both DDPS/KI and DTPS/KI precipitated spontaneously. The temperature-controlled self-separation behavior that can be achieved by modifying the length of the alkyl chain (Scheme 2) provided a convenient method to reuse catalysts. Meanwhile, the temperature-controlled phenomenon was observed in the reaction process for the catalytic system and listed in Fig. S3. Furthermore, the system of DTPS/KI was further investigated in detail.

\subsection{Catalytic performance of DTPS/KI for the coupling reaction}

Since pressure can play an important role in gas-liquid phase reactions, the effect of $\mathrm{CO}_{2}$ pressure on the reaction system was evaluated. As summarized in Fig. 1, the catalytic activity increased with the increase in $\mathrm{CO}_{2}$ pressure from 0.5 to 1.5 $\mathrm{MPa}$, thus increasing the product yield. Further increasing the pressure resulted in a sharp decline in the product yield, because of the reduction of the concentration of PO in the vicinity of the catalyst. The reaction was unfavorable at lower concentrations of the reactant, PO, as previously reported [80-82]. Therefore, the optimal reaction pressure is $1.5 \mathrm{MPa}$.

Temperature plays a significant role in organic reactions. The effect of reaction temperature in the range of 100 to $130{ }^{\circ} \mathrm{C}$ was investigated for the coupling reaction. As shown in Fig. 2, the yield of PC improved rapidly after the reaction reached 110 ${ }^{\circ} \mathrm{C}$, when the catalyst dissolved into the reaction system completely. When the temperature increased from 110 to $125^{\circ} \mathrm{C}$, an excellent yield of $95.1 \%$ was obtained. Although the PC yield

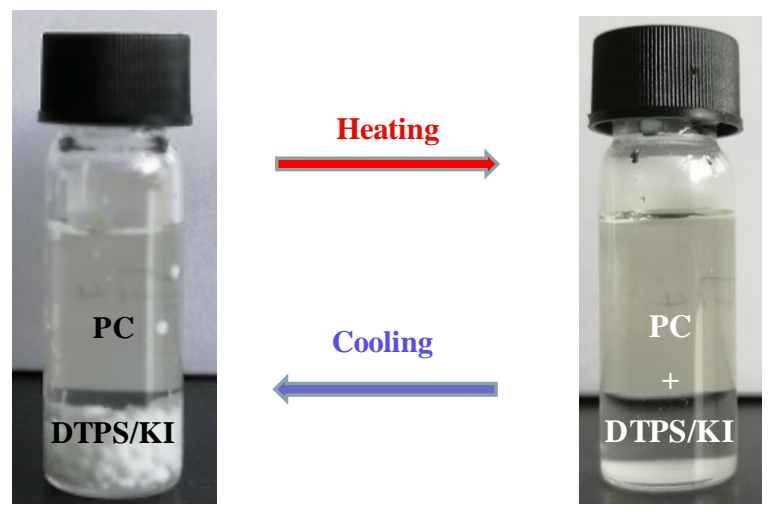

Scheme 2. Photograph of temperature controlled self-separation in PC by DTPS/KI.

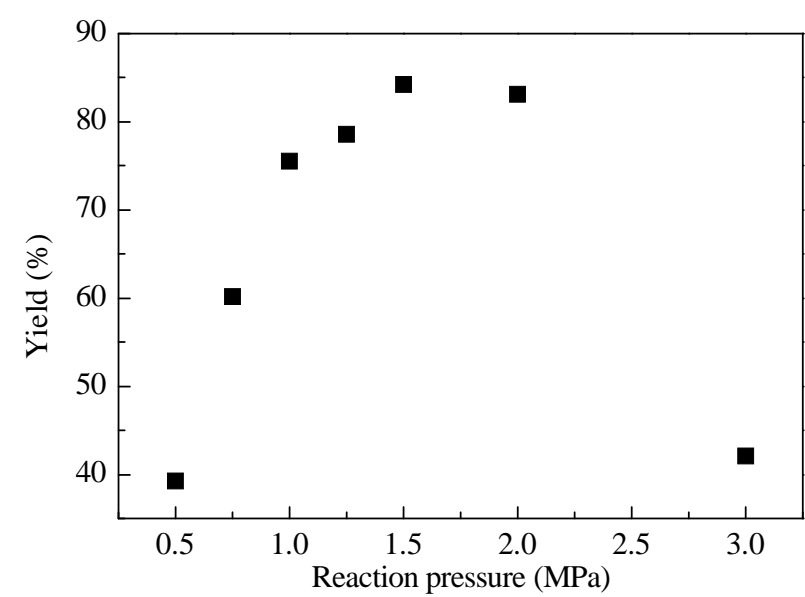

Fig. 1. Effect of pressure on the reaction catalyzed by DTPS/KI. Reaction conditions: PO $50 \mathrm{mmol}$, DTPS $1 \mathrm{~mol} \%$, KI $1 \mathrm{~mol} \%, 120^{\circ} \mathrm{C}, 5 \mathrm{~h}$. The selectivity to products is $>99 \%$ for all.

increased slightly, a light-yellow product without any by-product was collected at $130{ }^{\circ} \mathrm{C}$, since the yield of PC increased only slightly after $125^{\circ} \mathrm{C}$. Although the decomposition temperature of DTPS and DTPS/KI is above $210^{\circ} \mathrm{C}$, as shown in Fig. S4, the trace catalyst could be decomposed under the reaction conditions.

The PC yield is strongly affected by the catalyst loading of DTPS/KI in this coupling reaction in the range of 0.2 to 1.2 mol\%. As demonstrated in Fig. 3, at a low catalyst loading of DTPS/KI, insufficient active sites were available to promote the coupling reaction. Increasing the catalyst loading enhanced the activity of the catalyst system because of the increasing synergistic interaction between DTPS, epoxide, and KI. An excellent PC yield of $95.1 \%$ was observed at a catalytic loading of 1.0 mol\%. No significant increase in yield was observed by increasing the catalytic loading to higher than $1.0 \mathrm{~mol} \%$.

With regard to utilizing catalysts in several applications, the reusability of catalysts is an essential factor. A recycling experiment was carried out at the optimized condition. As shown in Fig. 4, the catalyst could be reused 4 times without signifi-

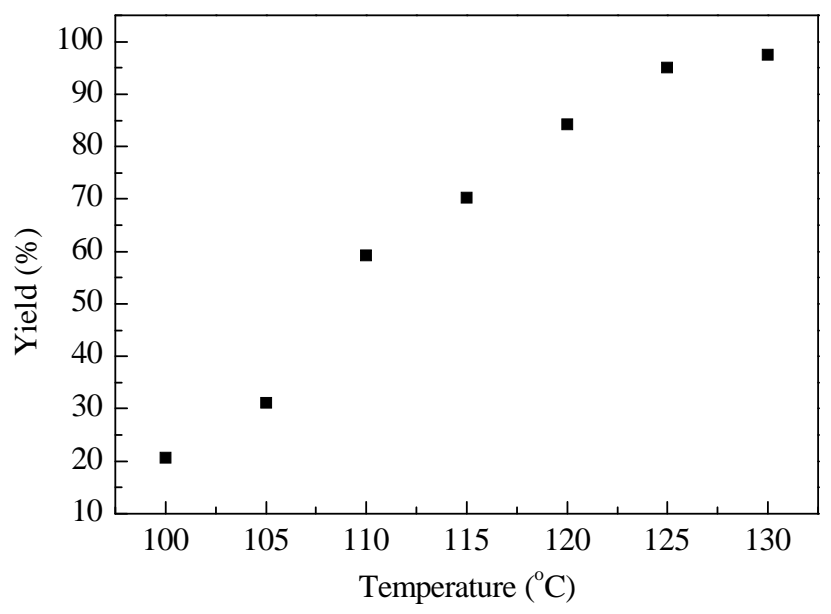

Fig. 2. Effect of temperature on the reaction catalyzed by DTPS/KI. Reaction conditions: PO $50 \mathrm{mmol}$, DTPS $1 \mathrm{~mol} \%$, KI $1 \mathrm{~mol} \%, 1.5 \mathrm{MPa}, 5$ h. The selectivity to products is $>99 \%$ for all. 


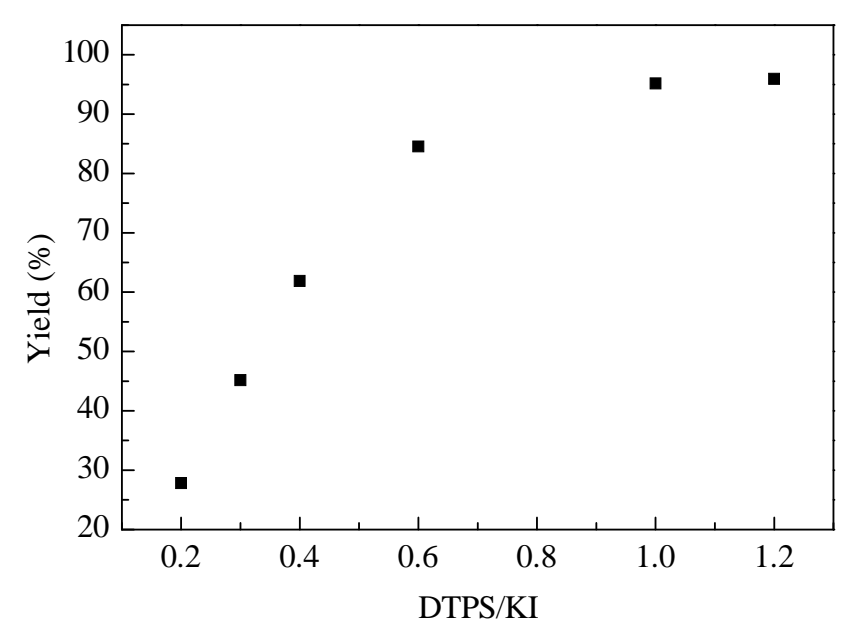

Fig. 3. Effect of catalytic loading on the reaction catalyzed by DTPS/KI. Reaction conditions: PO $50 \mathrm{mmol}, 1.5 \mathrm{MPa}, 125{ }^{\circ} \mathrm{C}, 5 \mathrm{~h}$. The selectivity to products is $>99 \%$ for all.

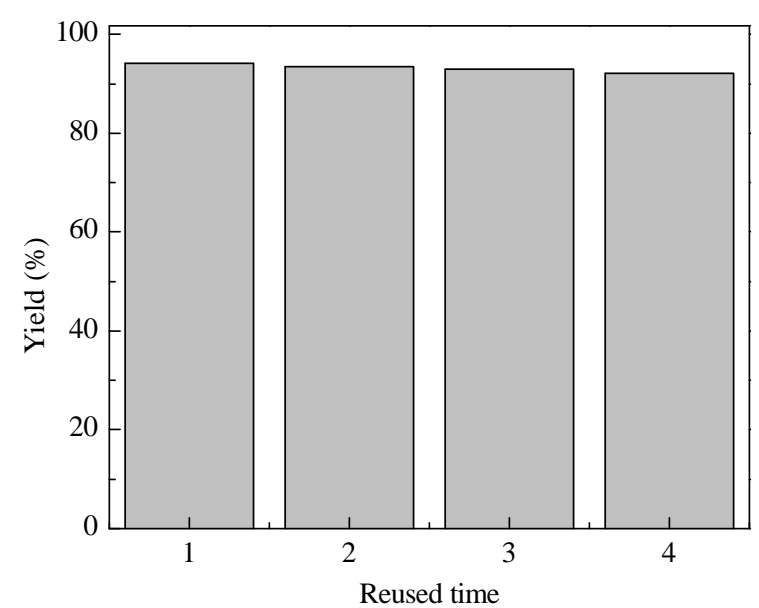

Fig. 4. Reuse of the catalyst DTPS/KI. Reaction conditions: PO $50 \mathrm{mmol}$, DTPS $1 \mathrm{~mol} \%$, KI $1 \mathrm{~mol} \%, 1.5 \mathrm{MPa}, 125^{\circ} \mathrm{C}$. The selectivity to products is $>99 \%$ for all.

cant loss of activity. The catalyst could be easily separated by centrifugation after use.

In terms of synthesis of cyclic carbonate, various epoxides catalyzed by DTPS/KI were investigated at optimized conditions to determine their applicability. As summarized in Table 2 , the catalytic system of DTPS/KI was compatible with a series of terminal epoxides and generated corresponding cyclic carbonates with excellent yields, although aromatic epoxide and cyclohexene oxide needed a longer reaction time because of steric hindrance.

\subsection{Mechanism}

As described in Table 1, an improved yield of PC was detected when both ZTQAs and KI were in the reaction. The interaction between ZTQAs and KI could weaken the interaction between $\mathrm{I}^{-}$and $\mathrm{K}^{+}$. This hypothesis was confirmed by the binding energies of KI and DTPS/KI, which are 619.0 and $618.1 \mathrm{eV}$ for $\mathrm{I}(3 d)$, and 293.0 and $292.5 \mathrm{eV}$ for $\mathrm{K}(2 p)$, respectively, as

\section{Table 2}

Coupling reaction of terminal epoxides.

\begin{tabular}{|c|c|c|c|c|}
\hline Entry & Epoxide & Product & Time (h) & Yield (\%) \\
\hline 1 & & & 5 & 95.1 \\
\hline 2 & $\mathrm{ClH}_{2} \mathrm{C}^{-}$ & & 8 & 90.2 \\
\hline 3 & $3 \mathrm{rH}_{2} \mathrm{C}^{-}$ & & 9 & 91.3 \\
\hline 4 & & & 12 & 96.6 \\
\hline 5 & & & 10 & 93.8 \\
\hline 6 & $\mathrm{Ph}^{-}$ & & 24 & 90.6 \\
\hline 7 & & & 6 & 96.5 \\
\hline 8 & 0 & & 24 & 93.1 \\
\hline
\end{tabular}

Reaction conditions: PO $50 \mathrm{mmol}$, DTPS $1 \mathrm{~mol} \%$, KI $1 \mathrm{~mol} \%, 1.5 \mathrm{MPa}$, $125^{\circ} \mathrm{C}$. The selectivity was determined by ${ }^{1} \mathrm{H}$ NMR to be $>99 \%$.

demonstrated in Fig. 5 and S5. To further explore the interaction between ZTQAs and KI, geometry optimization was calculated at the B3LYP/def2vp level of theory [83]. As shown in Fig. S6 and Table S1, an interaction was observed between $\mathrm{K}^{+}$and the oxygen atoms of sulfonate, which led to the reduction of the Mayer bond order of KI by approximately half. The Mayer bond order is a physical parameter that reflects the intensity between adjacent atoms [84], which can be calculated by a multifunctional wavefunction analyzer [85]. As a consequence, the

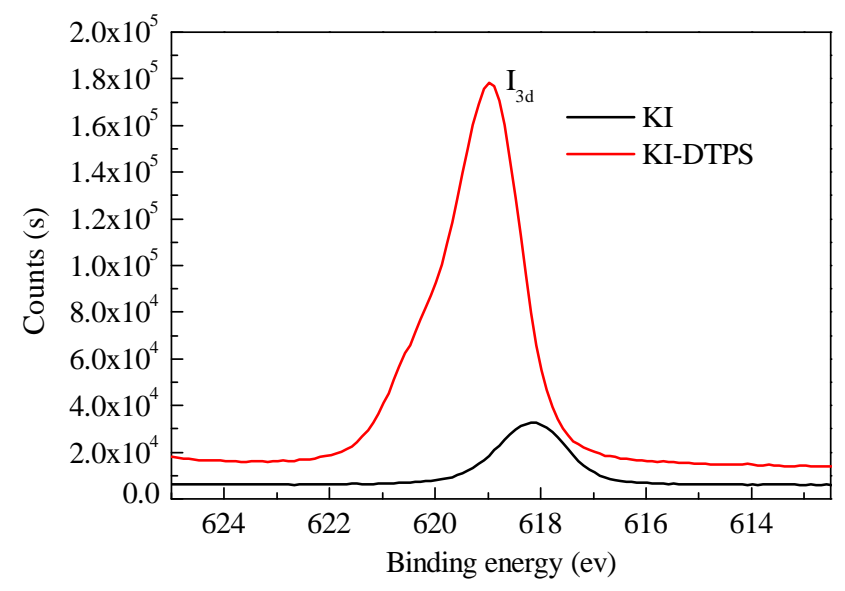

Fig. 5. Interaction of DTPS with KI, as detected by XPS. 


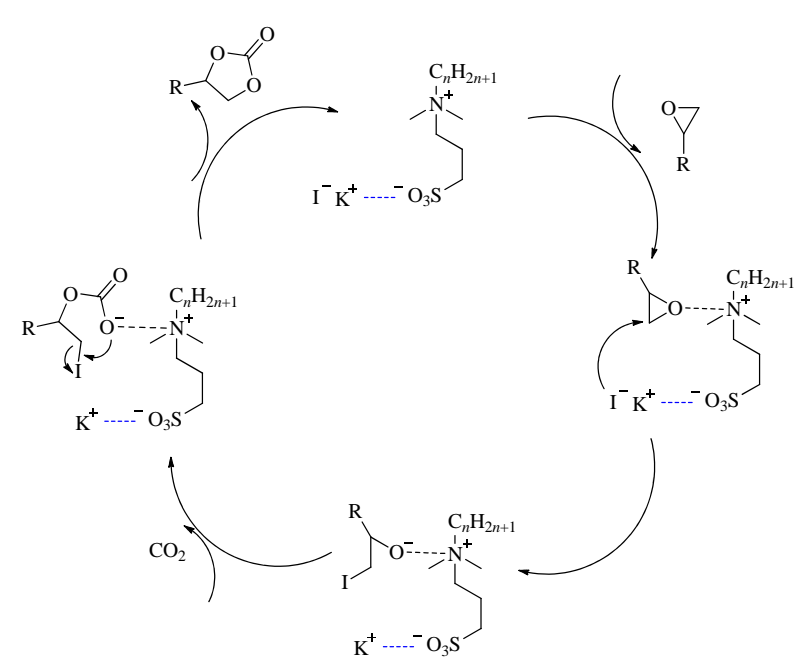

Scheme 3. Proposed mechanism.

nucleophilicity of $\mathrm{I}^{-}$was strengthened, which favored the coupling reaction. The proposed mechanism catalyzed by ZTQAs with $\mathrm{KI}$ is illustrated in Scheme 3. The sulfonate group in ZTQAs interacts with KI. Subsequently, the $\mathrm{I}^{-}$with increased nucleophilicity attacks the terminal carbon of the epoxide activated by the quaternary ammonium. This results in ring opening of the epoxide, which produces an alkoxide. Finally, after $\mathrm{CO}_{2}$ insertion into alkoxide intermediate, a cyclic carbonate is generated by intramolecular ring-closure, with subsequent regeneration of the catalyst.

\section{Conclusions}

The effect of the catalytic system of ZTQAs combined with $\mathrm{KI}$ on the coupling reaction of epoxides and carbon dioxide to synthesize cyclic carbonates was investigated. The ZTQAs with long alkyl chains exhibited temperature-responsive self-separation in PC. We can conclude that DTPS/KI was the most efficient system for the coupling reaction and can be used for various terminal epoxies, because the synergetic interaction between DTPS and KI efficiently promoted the coupling reaction. The behavior of self-separation provided an efficient approach to achieve high catalytic activity of the homogeneous catalyst and easy recovery of the heterogeneous catalyst.

\section{References}

[1] M. Alves, B. Grignard, R. Mereau, C. Jerome, T. Tassaing, C. Detrembleur, Catal. Sci. Technol., 2017, 7, 2651-2684.

[2] Q. W. Song, Z. H. Zhou, L. N. He, Green Chem., 2017, 19, 3707-3728.

[3] J. Artz, T. E. Müller, K. Thenert, J. Kleinekorte, R. Meys, A. Sternberg, A. Bardow, W. Leitner, Chem. Rev., 2018, 118, 434-504.

[4] M. Aresta, A. Dibenedetto, A. Angelini, Chem. Rev., 2014, 114, 1709-1742.

[5] X. B. Lu, D. J. Darensbourg, Chem. Soc. Rev., 2012, 41, 1462-1484.

[6] F. D. Meylan, V. Moreau, S. Erkman, J. CO 2 Util., 2015, 12, 101-108.

[7] G. Q. Yuan, C. R. Qi, W. Q. Wu, H. F. Jiang, Curr. Opin. Green Sustain. Chem., 2017, 3, 22-27.

[8] H. Arakawa, M. Aresta, J. N. Armor, J. N. Armor, M. A. Barteau, E. J. Beckman, A. T. Bell, J. E. Bercaw, C. Creutz, E. Dinjus, D. A. Dixon, K. Domen, D. L. DuBois, J. Eckert, E. Fujita, D. H. Gibson, W. A. Goddard, D. W. Goodman, J. Keller, G. J. Kubas, H. H. Kung, J. E. Lyons, L. E. Manzer, T. J. Marks, K. Morokuma, K. M. Nicholas, R. Periana, L. Que, J. Rostrup-Nielson, W. M. H. Sachtler, L. D. Schmidt, A. Sen, G. A. Somorjai, P. C. Stair, B. R. Stults, W. Tumas, Chem. Rev., 2001, 101, 953-996.

[9] P. P. Pescarmona, M. Taherimehr, Catal. Sci. Technol., 2012, 2, 2169-2187.

[10] B. H. Xu, J. Q. Wang, J. Sun, Y. Huang, J. P. Zhang, X. P. Zhang, S. J. Zhang, Green Chem., 2015, 17, 108-122.

[11] C. Martín, G. Fiorani, A. W. Kleij, ACS Catal., 2015, 5, 1353-1370.

[12] J. M. Comerford, Ian D. V. Ingram, M. North, X. Wu, Green Chem.,

\section{Graphical Abstract}

Chin. J. Catal., 2018, 39: 1854-1860 doi: 10.1016/S1872-2067(18)63101-8

\section{Temperature-responsive self-separation ionic liquid system of zwitterionic-type quaternary ammonium-KI for $\mathrm{CO}_{2}$ fixation}

Xiying Fu, Pengtao Xie, Yiwei Lian, Leqin He, Wei Zhao, Tao Chang *, Shenjun Qin *

Hebei University of Engineering; Handan College; Nanyang Normal University

A series of zwitterionic-type quaternary ammoniums with varying lengths of alkyl chains combined with KI were reported and considered as catalysts for the coupling reaction of $\mathrm{CO}_{2}$ and epoxides. They exhibited temperature-responsive self-separation in propylene carbonate.<smiles>[R]C1CO1</smiles>
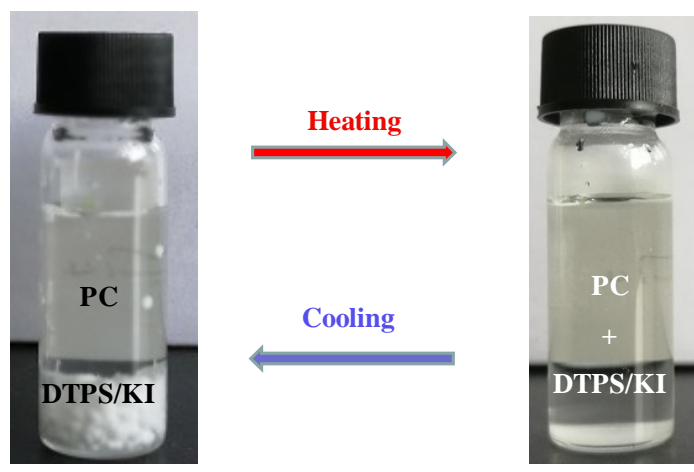
2015, 17, 1966-1987.

[13] D. W. Kim, R. Roshan, J. Tharun, A. Cherian, D.W. Park, Korean J. Chem. Eng., 2013, 30, 1973-1984.

[14] M. Mikkelsen, M. Jørgensen, F. C. Krebs, Energy Environ. Sci., 2010, 3, 43-81.

[15] Q. Li, J. Chen, L. Fan, X. Q. Kong, Y. Y. Lu, Green Energy Environ., 2016, 1, 18-42.

[16] B. Schäffner, F. Schäffner, S. P. Verevkin, A. Börner, Chem. Rev., 2010, 110, 4554-4581.

[17] P. Goodrich, H. Q. N. Gunaratne, J. Jacquemin, L. L. Jin, Y. T. Lei, K. R. Seddon, ACS Sustain. Chem. Eng., 2017, 5, 5635-5641.

[18] V. B. Saptal, B. M. Bhanage, ChemSusChem, 2016, 10, 1145-1151.

[19] L. Wang, K. Kodama, T. Hirose, Catal. Sci. Technol., 2016, 6, 3872-3877.

[20] M. Alves, B. Grignard, S. Gennen, R. Mereau, C. Detrembleur, C. Jerome, S. Tassaing, Catal. Sci. Technol., 2015, 5, 4636-4643.

[21] B. S. Wang, Z. J. Luo, E. H. M. Elageed, S. Wu, Y. Y. Zhang, X. P. Wu, F. Xia, G. R. Zhang, G. H. Gao, ChemCatChem, 2016, 8, 830-838.

[22] M. Adolph, T. A. Zevaco, C. Altesleben, S. Staudt, E. Dinjus, J. Mol. Catal. A, 2015, 400, 104-110.

[23] M. Taherimehr, J. P. C. C. Sertã, A. W. Kleij, C. J. Whiteoak, P. P. Pescarmona, ChemSusChem, 2015, 8, 1034-1042.

[24] T. Chang, L. L. Jin, H. W. Jing, ChemCatChem, 2009, 1, 379-383.

[25] C. Maeda, T. Taniguchi, K. Ogawa, T. Ema, Angew. Chem. Int. Ed., 2015, 54, 134-138.

[26] H. Büttner, K. Lau, A. Spannenberg, T. Werner, ChemCatChem, 2015, 7, 459-467.

[27] M. S. Liu, K. Q. Gao, L. Liang, F. X. Wang, L. Shi, J. M. Sun, Phys. Chem. Chem. Phys., 2015, 17, 5959-5965.

[28] T. Chang, X. R. Gao, L. Bian, X. Y. Fu, M. X. Yuan, H. W. Jing, Chin. J. Catal., 2015, 36, 408-413.

[29] M. S. Liu, B. Liu, S. F. Zhong, L. Shi, L. Liang, J. M. Sun, Ind. Eng. Chem. Res., 2015, 54, 633-640.

[30] R. C. Luo, X. T. Zhou, W. Y. Zhang, Z. X. Liang, J. Jiang, H. B. Ji, Green Chem., 2014, 16, 4179-4189.

[31] T. Werner, H. Büttner, ChemSusChem, 2014, 7, 3268-3271.

[32] A. M. Hardman-Baldwin, A. E. Mattson, ChemSusChem, 2014, 7, 3275-3278.

[33] A. J. Chen, C. Chen, Y. H. Xiu, X. R. Liu, J. Z. Chen, L. Guo, R. Zhang, Z. S. Hou, Green Chem., 2015, 17, 1842-1852.

[34] T. Ema, K. Fukuhara, T. Sakai, M. Ohbo, F. Q. Bai, J. Y. Hasegawa, Catal. Sci. Technol, 2015, 5, 2314-2321.

[35] M. H. Anthofer, M. E. Wilhelm, M. Cokoja, M. Drees, W. A. Herrmann, F. E. Kühn, ChemCatChem, 2015, 7, 94-98.

[36] S. Gennen, M. Alves, R. Méreau, T. Tassaing, B. Gilbert, C. Detrebleur, C. Jerome, B. Grignard, ChemSusChem, 2015, 8, 1845-1849.

[37] X. Y. Fu, X. Y. Jing, L . L. Jin, L. L. Zhang, X. F. Zhang, B. Hu, H. W. Jing, Chin. J. Catal., 2018, 39, 997-1003.

[38] X. Jiang, F. L. Gou, F. J. Chen, H. W. Jing, Green Chem., 2016, 18, 3567-3576.

[39] J. Steinbauer, L. Longwitz, M. Frank, J. Epping, U. Kragl, T. Werner, Green Chem., 2017, 19, 4435-4445.

[40] V. Besse, N. Illy, G. David, S. Caillol, B. Boutevin, ChemSusChem, 2016, 9, 2167-2173.

[41] S. Verma, R. I. Kureshy, T. Roy, M. Kumar, A. Das, N. H. Khan, S. H. R. Abdi, H. C. Bajaj, Catal. Commun., 2015, 61, 78-82.

[42] M. I. Kim, S. J. Choi, D. W. Kim, D. W. Park, J. Ind. Eng. Chem., 2014, 20, 3102-3107.

[43] L. C. Luo, X. T. Zhou, Y. X. Fang, H. B. Ji, Carbon, 2015, 82, 1-11.

[44] A. R. Hajipour, Y. Heidari, G. Kozehgary, RSC Adv., 2015, 5, 22373-22379.
[45] J. Sun, W. G. Cheng, Z. F. Yang, J. Q. Wang, T. T. Xu, J. Y. Xin, S. J. Zhang, Green Chem., 2014, 16, 3071-3078.

[46] J. Tharun, D. W. Kim, R. Roshan, Y. Hwang, D. W. Park, Catal. Commun., 2013, 31, 62-65.

[47] Y. Y. Zhang, S. F. Yin, S. L. Luo, C. T. Au, Ind. Eng. Chem. Res., 2012, 51, 3951-3957.

[48] J. Tharun, Y. Hwang, R. Roshan, S. Ahn, A. C. Kathalikkattil, D. W. Park, Catal. Sci. Technol, 2012, 2, 1674-1680.

[49] K. R. Roshan, G. Mathai, J. Kim, J. Tharun, G. A. Park, D. W. Park, Green Chem., 2012, 14, 2933-2940.

[50] M. S. Liu, B. Liu, L. Shi, F. X. Wang, L. Liang, J. M. Sun, RSC Adv,, 2015, 5, 960-966.

[51] M. Sankar, T. G. Ajithkumar, G. Sankar, P. Manikandan, Catal. Commun., 2015, 59, 201-205.

[52] X. M. Yan, X. Ding, Y. Pan, X. W. Xu, C. Hao, W. J. Zheng, G. H. He, Chin. J. Catal., 2017, 38, 862-871.

[53] S. Jayakumar, H. Li, Y. P. Zhao, J. Chen, Q. H. Yang, Chem. Asian J., 2017, 12, 577-585.

[54] L. He, C. Z. Li, J. Chen, L. N. Liu, Q. H. Yang, Chem. Asian J., 2017, 12, 1095-1103.

[55] M. L. Ding, H. L. Jiang, Chem. Commun., 2016, 52, 12294-12297.

[56] Q. Y. Deng, G. H. He, Y. Pan, X. H. Ruan, W. J. Zheng, X. M. Yan, RSC Adv., 2016, 6, 2217-2224.

[57] Y. Leng, D. Lu, P. P. Jiang, C. J. Zhang, J. W. Zhao, W. J. Zhang, Catal. Commun., 2016, 74, 99-103.

[58] M. S. Liu, K. Q. Gao, L. Liang, J. M. Sun, L. Sheng, M. Arai, Catal. Sci. Technol., 2016, 6, 6406-6416.

[59] T. Merner, N. Tenhumberg, H. Büttner, ChemCatChem, 2014, 6, 3493-3500.

[60] S. Ravi, D. H. Kang, R. Roshan, J. Tharun, A. C. Kathalikkattil, D. W. Park, Catal. Sci. Technol., 2015, 5, 1580-1587.

[61] M. S. Liu, B. Liu, L. Shi. F. X. Wang, L. Liang, J. M. Sun, RSC Adv., 2015, 5, 960-966.

[62] S. G. Liang, H. Z. Liu, T. Jiang, J. L. Song, G. Y. Yang, B. X. Han, Chem. Commun., 2011, 47, 2131-2133.

[63] Y. Y. Song, C. Cheng, H. W. Jing, Chem. Eur. J., 2014, 20, 12894-12900.

[64] X. Liu, S. Zhang, Q. W. Song, X. F. Liu, R. Ma, L. N. He, Green Chem., 2016, 18, 2871-2876.

[65] J. Steinbauer, T. Werner, ChemSusChem, 2017, 10, 3025-3030.

[66] J. L. Song, B. B. Zhang, P. Zhang, J. Ma, J. L. Liu, H. L. Fan, T. Jiang, B. X. Han, Catal. Today, 2012, 183, 130-135.

[67] Z. F. Yang, J. Sun, W. G. Cheng, J. Q. Wang, Q. Li, S. J. Zhang, Catal. Commun., 2014, 44, 6-9.

[68] Y. Kohno, H. Ohno, Phys. Chem. Chem. Phys., 2014, 14, 5063-5070.

[69] Y. Kohno, S. Saita, Y. J. Men, J. Y. Yuan, H. Ohno, Polym. Chem., 2015, 6, 2163-2178.

[70] Y. X. Qiao, W. B. Ma, N. Theyssen, C. Chen, Z. S. Hou, Chem. Rev., 2017, 117, 6881-6928.

[71] X. Jin, D. X. Yang, X. F. Xu, Z. Q. Yang, Chem. Commun., 2012, 48, 9017-9019.

[72] Y. P. Hao, J. Y. Jiang, Y. H. Wang, Z. L. Jin, Catal. Commun., 2015, 71, 106-110.

[73] M. D. Zhou, M. J. Liu, L. L. Huang, J. Zhang, J. Y. Wang, X. B. Li, F. E. Kühn, S. L. Zang, Green Chem., 2015, 17, 1186-1193.

[74] Z. Sun, L. F. Xue, S. T. Wang, X. H. Wang, J. Y. Shi, Green Chem., 2016, 18, 742-752.

[75] J. Luo, T. T. Xin, Y. L. Wang, New J. Chem., 2013, 37, 269-273.

[76] X. X. Duan, G. R. Sun, Z. Sun, J. X. Li, S. T. Wang, X. H. Wang, S. W. Li, Z. J. Jiang, Catal. Commun., 2013, 42, 125-128.

[77] X. L. Meng, H. Y. He, Y. Nie, X. P. Zhang, S. J. Zhang, J. J. Wang, ACS Sustain. Chem. Eng., 2017, 5, 3081-3086. 
[78] L. Q. He, S. J. Qin, T. Chang, Y. Z. Sun, X. R. Gao, Catal. Sci. Technol., 2013, 3, 1102-1107.

[79] T. Chang, L. Q. He, L. Bian, H. Y. Han, M. X. Yuan, X. R. Gao, RSC Adv., 2014, 4, 727-731.

[80] J. Peng, S. Wang, H. J. Yang, B. R. Ban, Z. D. Wei, L. H. Wang, B. Lei, Fuel, 2018, 224, 481-488.

[81] J. Peng, Y. C. Geng, H. J. Geng, H. J. Yang, W. He, Z. D. Wei, J. K. Yang, C. Y. Guo, Mol. Catal., 2017, 432, 37-46.

[82] J. Peng, H. J. Yang, S. Wang, B. R. Ban, Z. D. Wei, B. Lei, C. Y. Guo, J. $\mathrm{CO}_{2}$ Util., 2018, 24, 1-9.

[83] M. J. Frisch, G. W. Trucks, H. B. Schlegel, G. E. Scuseria, M. A. Robb, J. R. Cheeseman, G. Scalmani, V. Barone, B. Mennucci, G. A. Petersson, H. Nakatsuji, M. Caricato, X. Li, H. P. Hratchian, A. F.
Izmaylov, J. Bloino, G. Zheng, J. L. Sonnenberg, M. Hada, M. Ehara, F. Toyota, M. Bearpark, J. J. Heyd, E. Brothers, K. N. Kudin, V. N. Staroveroe, R. Kobayashi, J. Normand, K. Raghavachari, A. Rendell, J. C. Burant, S. S. Iyengar, J. Tomasi, M. Cossi, N. Raga, J. M. Millam, M. Klene, J. E. Knox, J. B. Cross, V. Bakken, C. Adamo, J. Jaramillo, R. Comperts, R. E. Stratmann, O. Yazyev, A. J. Austin, R. Cammi, C. Pomelli, J. W. Ochterski, R. L. Martin, K. Morokuma, V. G. Zakrzewski, G. A. Voth, P. Salvador, J. J. Dannenberg, S. Dapprich, A. D. Daniels, O. Farkas, J. B. Foresman, J. V. Ortiz, J. Cioslowski, D. J. Fox, Gaussian 09, Revision D.01, Gaussian, Inc., Wallingford, CT, 2009.

[84] I. Mayer, J. Comput. Chem., 2007, 28, 204-221.

[85] T. Lu, F. W. Chen, J. Comput. Chem., 2012, 33, 580-592.

\title{
基于两性离子型季铵盐-KI的温度控制自分离离子液体(IL)催化体系 用于二氧化碳固定反应
}

\author{
付西英 ${ }^{\mathrm{a}, \dagger}$, 谢鹏涛 ${ }^{\mathrm{b}, \dagger}$, 连一苇 ${ }^{\mathrm{a}}$, 何乐芹 ${ }^{\mathrm{a}}$, 赵 伟 ${ }^{\mathrm{c}}$, 常 涛, ${ }^{\mathrm{a}}$, 秦身钧, ${ }^{\mathrm{a},}$

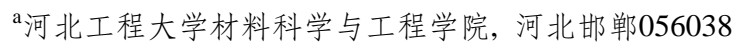

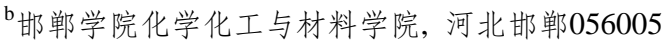 \\ c南阳师范学院化学与制药工程学院, 河南南阳 473061
}

摘要: 随着在世界各国工业化进程不断加快, 人类对煤、石油、天然气等化石燃料的需求越来越大, 既加速了能源短缺, 又 排放了大量 $\mathrm{CO}_{2} . \mathrm{CO}_{2}$ 又成为分布最广、价格便宜和储量丰富的碳资源. 人类除了努力做到 $\mathrm{CO}_{2}$ 减排, 又可将其转化为能源、 材料和各种化工产品. $\mathrm{CO}_{2}$ 与环氧化合物发生偶联反应生成环碳酸酯, 具有原子经济性, 符合绿色化学的观点, 是最有前景 的方法之一. $\mathrm{CO}_{2}$ 可以与三元环氧化合物发生偶联反应生成五元环状碳酸酯, 它是当今合成环碳酸酯比较成熟的方法. 已 经被设计合成并应用的高效催化体系有离子液体催化剂、金属盐或氧化物催化剂、有机催化剂、希夫碱金属配合物催化 剂以及大环金属配合物催化剂等等, 但最有效的催化剂还是均相催化剂, 其最大的缺点在于催化剂和产物分离困难. 既有 均相催化剂高的催化活性, 又能像多相催化剂易于分离, 是人们设计新催化剂的目标.

本文设计合成了一系列含有不同烷基链长度的两性离子型季铵盐(ZTQAs), 可以与KI协同催化 $\mathrm{CO}_{2}$ 与环氧化合物偶联 反应. 随着烷基链的增长, ZTQAs在碳酸丙烯酯中表现出温度调控的自分离特性. 通过X射线光电子能谱和量子化学计算 证实, ZTQAs与KI之间存在明显的相互作用, 从而增强了碘离子的亲核能力. 当反应条件为 $12{ }^{\circ} \mathrm{C}, \mathrm{CO}_{2}$ 压力 $1.5 \mathrm{MPa}$ 以及 1 mol\%催化剂用量下, DTPS/KI催化剂取得了良好的收率(95.1\%). 并且该催化剂可以从催化系统中自发的析出, 因而既表现 出均相催化剂的高活性, 又可以像非均相催化剂那样循环使用. 该催化剂催化各种环氧化合物与 $\mathrm{CO}_{2}$ 偶联反应中均显示出 良好的催化性能.

关键词: 二氧化碳; 自分离; 环碳酸酯; 两性离子型季铵盐; 碘化钾

收稿日期: 2018-03-31. 接受日期: 2018-05-14. 出版日期: 2018-11-05.

*通讯联系人. 电话/传真: (0310)8578760; 电子信箱: changtao@hebeu.edu.cn

\#通讯联系人. 电话/传真: (0310)8577902; 电子信箱: qinsj528@hebeu.edu.cn

†共同第一作者.

基金来源：国家自然科学基金(41330317, 21403051); 河北省自然科学基金(B2016402030, B2017402079); 河北省高等学校科学研 究项目(ZD2015113); 邯単市科学技术研究与发展计划(1621211041-3, 1622201049-2); 河北省高校百名创新人才项目(BR2-204). 本文的电子版全文由Elsevier出版社在ScienceDirect上出版(http://www.sciencedirect.com/science/journal/18722067). 